\title{
Pattern and Differential of Literacy in Madhya Pradesh
}

\author{
Ghanshyam Prasad Jhariya ${ }^{1}$, Dr. C.K.Jain ${ }^{2}$ \\ ${ }^{I}$ Research Scholar, Department of Geography, Dr. Hari Singh Gour University Sagar, M. P., India, \\ ${ }^{2}$ Reader, Department of Geography, Dr. Hari Singh Gour University Sagar, M. P., India.
}

\begin{abstract}
Literacy is an important demographic element of human process. It is essential for human character, social and economic development. It contribute to better health, higher productivity, high income, capability and esteemed living, increased participation in community life. Education includes new ideas for a better building of the society and their personal life style.

The present work is an attempt to study the trends and pattern and their differential (Male-female and urbanrural) of literacy in Madhya Pradesh. It sustain about 7.25crore out of about 121crore of India's total population but literacy rate is for below the national average. The study is based on data from the census of India 2001 and 2011. The male -female and rural-urban differential has been worked out. The literacy rate of Madhya Pradesh was 70.63 Percent in 2011. Moreover, there are remarkable gaps between male and female and between rural and urban rates in the state.
\end{abstract}

Keywords: trends of literacy, spatial pattern, literacy differential index, regional variation.

\section{Introduction}

Literacy is an important demographic element and it is a good measure of human progress. It is essential for social reconstruction, improvement in quality of life and preparation of manpower for rapid development. Education inculcates new ideas for betterment of the society in particular and nation in general. The high literacy rate is one of the very significantly qualitative indicators of social development associated to the economic development. Even today education is the most instrisinsis instrument for changing the socio economic status of an individual and society as a whole. According to an old proverb, a man without education is a best without its horns or tail. He is a burden on the earth and a parasite on society. According to Mahatma Gandhi the purpose of education is to establish a non- violent, non- exploitative, social and economic order. Education is a highway to that goal. Keeping on this view of this accepted fact there has been a major thrust on education since independence; but a far as earning quality in India is concerned is has always been one of the biggest challenges for the government (Som and Mishra, 2014).

In international usages, literacy is defined as the ability to read, write and least a simple massage in any language (Hassan, 2005). Indian census considers a person as literate if he/ she can both read and write in any language (Chandna, 2009). That the why, literacy rates in India calculated excluding 0-6 age group of population. There is no denying the fact that India is still in the midst of its literacy transition. Consequently, the country is characterized by low but improving literacy rates.

One notable feature of India's population is that the females lag far behind the males in term of literacy. While three out of every four males could read and write of the country, the corresponding figure for the females was about two out of every four. Such male female differentials in literacy were the product of the country's history and its socio economic political milieu. Largely farm based economic setup, general poverty, caste based social structure, prejudices against female mobility, education and employment, limited facilities for schooling, poor infrastructure in schools, proxy teachers, high incidence of dropouts and child marriage are some of the factors that may have contributed to the show pace of literacy transition in the country (chandna, 2009).

India has recorded a literacy rate of 74.0 percent with the rural areas reporting a literacy rate of 68.9 percent and the urban areas registering 85.0 percent literacy; resulting in an absolute difference of nearly 16 percent. The difference in the rural and urban female literacy rates is skewed in the favour of the urban areas with a difference of more than 20 percentage points. The pronounced difference in the rural-urban distribution proves that significant efforts need to be undertaken to improve the literacy status in the rural areas.

In Madhya Pradesh the total literacy rate is pegged at 70.6 percent with the rural areas registering 65.3 percent and the urban areas reporting a figure of 84.1 percent. The gap in literacy is nearly double in the rural areas as compared to the urban areas which act as a hurdle in the development strategy of the state. However, several government initiatives in the form of programmes and schemes have been undertaken to narrow the gender gap with a perspective to enhance human capital in the country.

Elementary education is important millennium development goal for the government. To achieve the goal, "Right to Education Act" is came since $1^{\text {st }}$ April, 2010 in the entire country for every child between the 
age of six and fourteen year to demand free and elementary education. Improvement of education, people can employ modern tools and techniques and improvement of their productivity and earning potentials, and benefit their own welfare and that of the country.

\section{The Study Area}

Madhya Pradesh is the second largest state of the country with an area of $308245 \mathrm{~km} 2$ constituting $9.38 \%$ of total geographical area of the country. It lies between latitude of $21017^{`} \mathrm{~N}$ and $26052{ }^{\prime} \mathrm{N}$ and the longitudes of $78 \mathrm{o} 08^{\circ} \mathrm{E}$ and $82 \mathrm{o} 49^{\circ} \mathrm{E}$. physiologically, the state can be divided into four regions, viz. the low lying area of north and north west of Gwalior, Malwa plateau, Satpura and Vindhyan range. Betwa, Chambal, Sone and Narmada are four important river of the state. Average annual rainfall varies from $800 \mathrm{~mm}$ to about $1800 \mathrm{~mm}$. the annual temperature range from $22.5 \mathrm{oC}$ to $25 \mathrm{oC}$ (Kumar,pramila,2000).

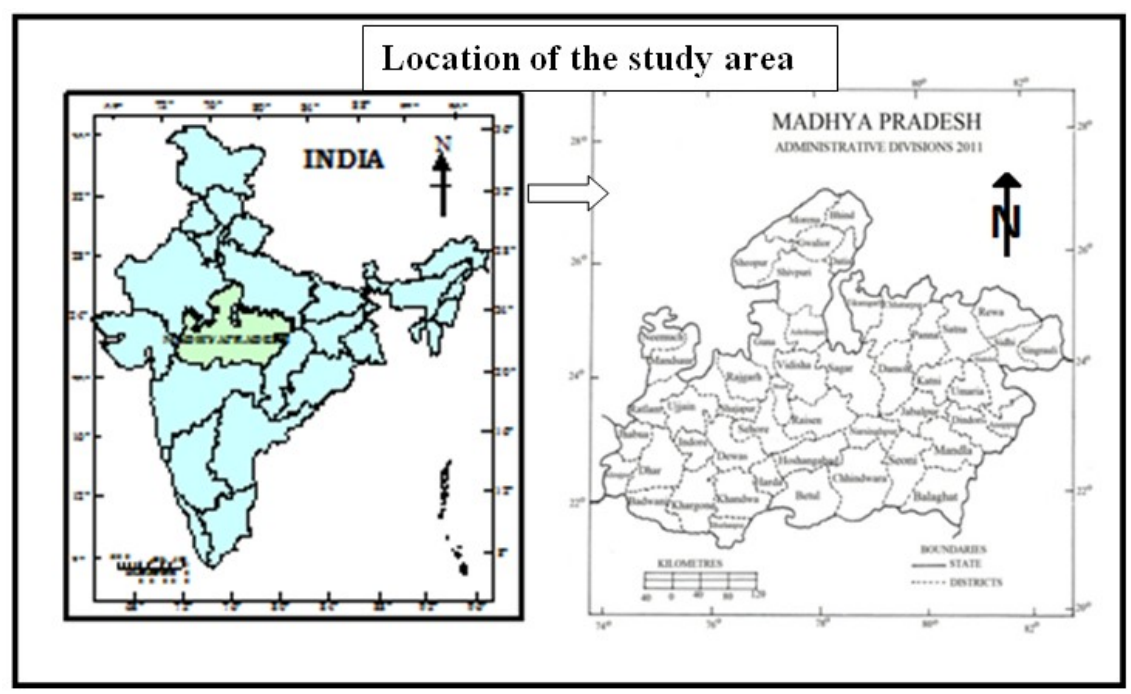

Fig. 1 Location of the Study Area

The total population of the state is 72597565 (census2011) which constitute $5.998 \%$ of the country's population. Of this, rural population is $72.37 \%$ and urban population is $27.63 \%$. The population density is 236 Person per km2. The livestock population is 40.70 million (livestock census 2007).

The northern border of the state has two neighbor states namely the state of Rajasthan and Uttar Pradesh. The western border of the state is shared by a part of Rajasthan and a part of Maharashtra with Gujarat in between. On the southern part of the state Madhya Pradesh lie the states Maharashtra and Andhra Pradesh. The entire eastern border of the state is bounded by the state of Chhattisgarh and Jharkhand.

\section{Objectives}

The main objective of the present study is to attempt an analysis of the literacy level in the state.

1. To analysis the spatial pattern of literacy rate in the state (at the district level), 2011.

2. To analysis the segment disparity in literacy (Gender, Rural- Urban) in the state, 2011.

\section{Database and Methodology}

The data for the following analysis have been obtained from Census of India 2001and 2011. It examines the special and deferential pattern of literacy two levels: state and district. In present time 50 district in the state, while in 2001 there are 45 districts. For the sake of comparison, newly farmed district has been treated as a part of the present unit.

The data have been analyzed with the help of statistical tables and Choropleth techniques for showing the disparity pattern of literacy and presented by applying differential Index is follows:

1. $\mathrm{MFDI}=(\mathrm{MLR}-\mathrm{FLR}) / \mathrm{TLR}$

2. $\mathrm{URDI}=(\mathrm{ULR}-\mathrm{RLR}) / \mathrm{TLR}$

Where- MFDI $=$ Male Female Differential Index, URDI= Urban Rural differential Index, MLR $=$ Male Literacy Rate, $\mathrm{FLR}=$ Female Literacy Rate, $\mathrm{TLR}=$ Total Literacy Rate, ULR= Urban Literacy Rate, RLR= Rural literacy Rate. After using these methods, the result is divided into five categories like: very low, low, moderate, high and very high. For this study data and information has been collected with the help of books, magazines, research articles and report of national census. 


\section{Review of Previous Work}

Bahadur and Ahmad, (1981) presented a study on inequalities in higher education in India. He measured the extent of the regional disparities of the educational structure in different universities.

Dube and Mishra, (1981) have analyzed level of literacy in India and have conclude that progress of literacy is one of the important indicator of development in a region.

Mishra, (1995) has analyzed different aspect of literacy in Madhya Pradesh. Mishra and Shukla (1999) have analyzed the relation between literacy and fertility in Sagar district, Madhya Pradesh.

Chandna, (2001) has described basic concepts, differentials, determinants and spatial pattern of literacy in different part of the world. He was also analyzed the progress of literacy in India. Chourasia, (2007) has analyzed some aspects of literacy in Madhya Pradesh.

\section{Trends of Literacy Rate In Madhya Pradesh: An Overview}

Census is the main source of literacy data in India. Data on literacy have been collected ever since the counting began in the country in $1872 \mathrm{how}$ ever, the concept of literacy and education has undergone significant change over time. Up to the 1891 census, the population was classified into three groups -literate, illiterate and under instruction. The last group includes attending schools or colleges or private institutions.

Despite the fact that India and Madhya Pradesh has been a land of ancient tradition of literacy and education, the country's population has been marked with an abysmally low level of literacy ever at the time census operations began in the country.

In spite of impressive progress of literacy during the recent decades, Madhya Pradesh lies at the bottom of literacy rate in the country. The male literacy was 80.50 percent whereas that of female was 60.0 percent in 2011. The urban and rural literacy were recorded as 84.1 percent and 65.3 percent respectively (2011).

The literacy, in the state of Madhya Pradesh was $13.16 \%$ in 1951 and since then there has been considerable increase in the literacy rate till 2001 afterwards it increased steadily in 2011. The literacy rate increase by 8.25 percent during 1961, 5.86 percent during 1971, 11.36 percent during 1981.6 .04 percent during 1991, recorded a sizeable improvement of 19.07 percent during 2001 and 6.89 percent in 2011(table1). The literacy rate of the population in twentieth century has shown a gradual increasing trend in India since 1951 except some marginal improvements in the Censuses of 1981, 2001 and now 2011. The literacy during 19512011 increased to57.47 percent in the Madhya Pradesh and 55.71 percent in India. As obvious, the increase in literacy rate was medium in Madhya Pradesh than in the country as a whole. However, the sex ratio of the state remained lower than that of the country throughout since 2001 to date.

Table: 1. Compare of Literacy Rate

\begin{tabular}{|l|l|l|}
\hline $\begin{array}{l}\text { Census } \\
\text { Year }\end{array}$ & Madhya Pradesh & India \\
\hline 1951 & 13.16 & 18.33 \\
\hline 1961 & 21.41 & 28.3 \\
\hline 1971 & 27.27 & 34.45 \\
\hline 1981 & 38.63 & 43.57 \\
\hline 1991 & 44.67 & 52.21 \\
\hline 2001 & 63.74 & 64.84 \\
\hline 2011 & 70.63 & 74.04 \\
\hline
\end{tabular}

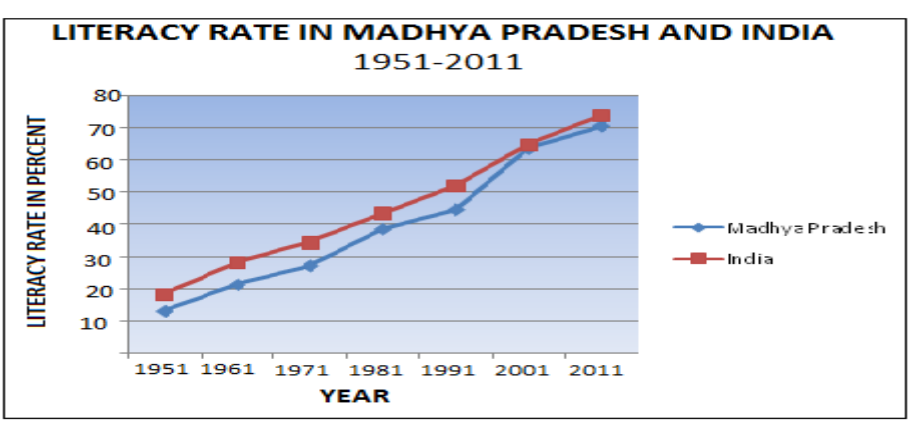

Fig. 2 Trends of Literacy Rate, Madhya Pradesh and India

The increase in literacy was the result of opening a large number of schools with the help of different agencies like UNICEF, Private societies and government policies towards the universalisation of education. The launch of "Literacy Mission" has been one of the most significant steps in the field of literacy. Despite recent increase of literacy, the state still records high percentage of illiterates.

\section{Spatial Pattern of Literacy Rate, 2011}

District wise pattern of literacy rate indicated that it varied largely from one part of the state to another. For showing the spatial pattern of literacy of Madhya Pradesh is divided into four categories and each category are divided into five part (i) very low, (ii) low, (iii) moderate, (iv) high and (v) very high.

\section{Spatial Pattern of General Literacy Rate}

The district wise distribution of literacy rate in Madhya Pradesh is not uniform. It varies from 37.2 in Alirajpur district to 82.5 in Jabalpur District (table 2). State average (70.06) stands somewhat midway between the two extremes and lies well below the national average (74.04). The scarcity of females, though a common 
feature is however, of relatively considerable magnitude in Madhya Pradesh. On the basis of this significantly large range of spatial variations the state has been divided into five broad categories.

Table: 2. Variations of General Literacy Rate of Madhya Pradesh, 2011

\begin{tabular}{|l|l|l|}
\hline $\begin{array}{l}\text { Categories of } \\
\text { literacy tare }\end{array}$ & No. of districts \\
\hline $\begin{array}{l}\text { Very high (more } \\
\text { than } 80 \%)\end{array}$ & 3 & Indore, Bhopal, Jabalpur \\
\hline High (70-80\%) & 25 & $\begin{array}{l}\text { Anuppur, Morena, bhind, datia, Gwalior, sagar, damoh, satna, } \\
\text { rewa, neemuch, mandsour, Ujjain, shajapur, dewas, vidisha, } \\
\text { sehore, raisen, betul, harda, hoshangabad, katni, narsinghpur, } \\
\text { chhindwara, seoni, balaghat }\end{array}$ \\
\hline $\begin{array}{l}\text { Moderate (60- } \\
70 \%)\end{array}$ & 18 & $\begin{array}{l}\text { Ashoknagar, shivpuri, guna, tikamgarh, chhatarpur, panna, } \\
\text { sidhi, singrouli, umaria, dindori, shahdol, ratlam, dhar, } \\
\text { khargone, khandwa, burhanpur, rajgarh, mandla }\end{array}$ \\
\hline $\begin{array}{l}\text { Low (50-60\%) } \\
\text { Very low (less } \\
\text { than 50\%) }\end{array}$ & 2 & \begin{tabular}{l} 
Sheopur, badwani \\
\hline
\end{tabular} \\
\hline
\end{tabular}

It can be observed from the table that quit small part of the state i.e., about 4 percent of the districts namely Alirajpur and Jhabua have emerged as a region of considerably very low literacy rate up to $50 \%$. This region lies in the south western part of the state. This region lies in the south western part of the state.

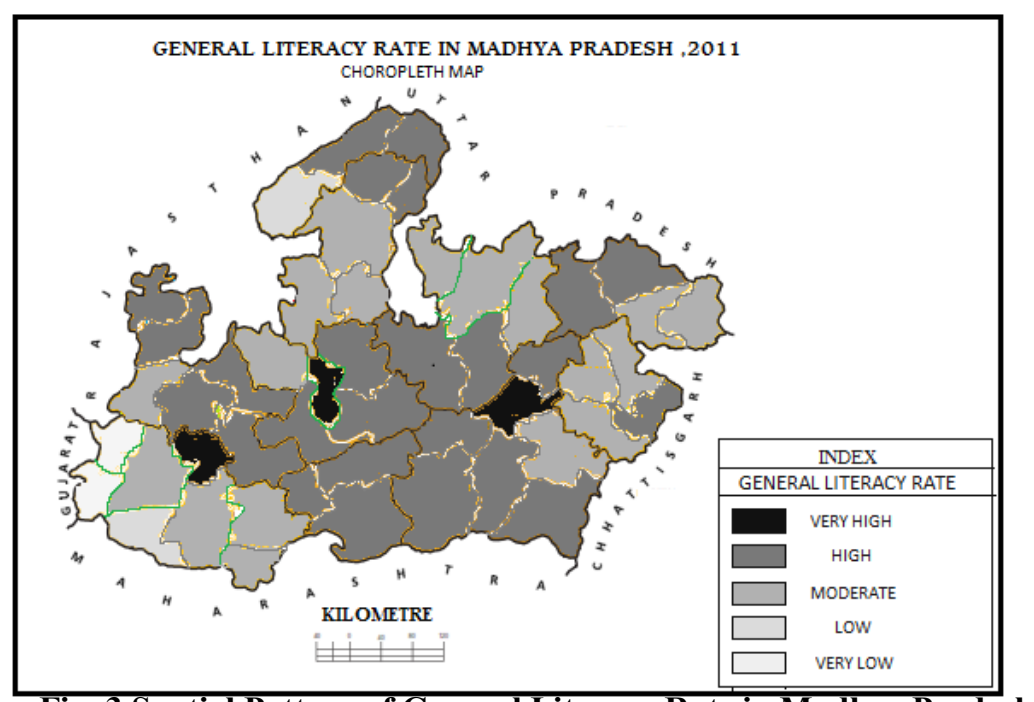

Fig. 3 Spatial Pattern of General Literacy Rate in Madhya Pradesh

4 per cent of the districts fall under the low literacy rate (50-60\%), 18 districts under the category of moderate literacy rate $(60-70 \%)$. The fourth subdivision defined by high grade of literacy rate $(70-80 \%)$ comprising 25 districts is divided into four regions; one lies in the extremely northern margin of the state while the other is located in the south and central part of the state and two small region is located in north western part and eastern part of the state.

The last category of very high literacy rate (more than $80 \%$ ) consists of only three districts Jabalpur (82.5\%), Indore (82.3\%) and Bhopal (82.3\%). The reason for this high literacy rate may be:

$>\quad$ Availability of better educational facilities in the town and cities.

$>\quad$ Higher awareness about the literacy among urban people.

$>\quad$ The greater functional necessity of literacy for employment and lesser utility of children for parent's occupation in urban areas. 
Table: 3. District-Wise Literacy Rate and differential in Madhya Pradesh, 2011

\begin{tabular}{|c|c|c|c|c|c|c|c|c|}
\hline S1.No. & $\begin{array}{l}\text { Name of the } \\
\text { Districts }\end{array}$ & $\begin{array}{l}\text { Total } \\
\text { literacy } \\
\text { rate }\end{array}$ & $\begin{array}{l}\text { Male } \\
\text { literacy } \\
\text { rate }\end{array}$ & $\begin{array}{l}\text { Female } \\
\text { literacy } \\
\text { rate }\end{array}$ & $\begin{array}{l}\text { Male-Female } \\
\text { differetial }\end{array}$ & $\begin{array}{l}\text { Rural } \\
\text { literacy } \\
\text { rate }\end{array}$ & $\begin{array}{l}\text { Urban } \\
\text { literacy } \\
\text { rate }\end{array}$ & $\begin{array}{l}\text { Rural-Urban } \\
\text { differential }\end{array}$ \\
\hline \multicolumn{2}{|c|}{ Madhya Pradesh } & 70.66 & 80.50 & 60.0 & 0.29 & 65.3 & 84.1 & 0.27 \\
\hline 2 & Morena & 72.1 & 84.2 & 57.6 & 0.36 & 69.9 & 78.7 & 0.12 \\
\hline 3 & Bhind & 76.6 & 87.2 & 64.0 & 0.30 & 75.4 & 80.0 & 0.06 \\
\hline 4 & Gwalior & 77.9 & 86.3 & 68.3 & 0.23 & 67.0 & 84.2 & 0.22 \\
\hline 6 & Shivpuri & 63.7 & 76.2 & 49.5 & 0.42 & 60.6 & 68.7 & 0.12 \\
\hline 7 & Guna & 65.1 & 76.6 & 52.5 & 0.37 & 60.3 & 78.7 & 0.28 \\
\hline 8 & Ashoknagar & 67.9 & 80.2 & 54.2 & 0.38 & 65.3 & 79.3 & 0.21 \\
\hline 9 & Tikamgarh & 72.6 & 73.3 & 50.7 & 0.31 & 59.8 & 75.7 & 0.22 \\
\hline 10 & Chhatarpur & 74.9 & 74.2 & 54.3 & 0.27 & 60.4 & 79.7 & 0.26 \\
\hline 11 & Panna & 66.1 & 75.6 & 55.6 & 0.30 & 63.9 & 80.6 & 0.25 \\
\hline 15 & Rewa & 73.4 & 83.7 & 62.5 & 0.29 & 71.4 & 83.3 & 0.16 \\
\hline 16 & Sidhi & 66.1 & 76.5 & 55.2 & 0.32 & 64.8 & 79.9 & 0.23 \\
\hline 17 & Singrauli & 62.4 & 73.8 & 49.9 & 0.38 & 58.5 & 77.6 & 0.31 \\
\hline 18 & Umaria & 67.3 & 78.1 & 56.1 & 0.33 & 64.5 & 80.3 & 0.23 \\
\hline 19 & Dindori & 65.5 & 77.6 & 53.5 & 0.37 & 64.4 & 86.7 & 0.34 \\
\hline 20 & Shahdol & 68.4 & 78.3 & 58.2 & 0.29 & 64.0 & 84.4 & 0.30 \\
\hline 21 & Anuppur & 69.1 & 80.1 & 57.9 & 0.32 & 64.3 & 81.3 & 0.25 \\
\hline 22 & Neemuch & 71.8 & 85.9 & 57.3 & 0.40 & 66.8 & 83.5 & 0.23 \\
\hline 23 & Mandsaur & 72.7 & 86.8 & 58.3 & 0.39 & 69.6 & 84.6 & 0.21 \\
\hline 24 & Ratlam & 67.0 & 79.4 & 56.5 & 0.34 & 60.8 & 84.2 & 0.40 \\
\hline 25 & Ujjain & 73.6 & 85.2 & 61.4 & 0.32 & 66.6 & 83.4 & 0.23 \\
\hline 33 & Alirajpur & 37.2 & 43.6 & 31.0 & 0.34 & 33.2 & 81.0 & 1.28 \\
\hline 34 & Khandwa & 67.5 & 77.9 & 56.5 & 0.32 & 63.3 & 85.0 & 0.32 \\
\hline 35 & Burhanpur & 65.3 & 73.1 & 57.1 & 0.25 & 56.9 & 80.5 & 0.26 \\
\hline 36 & Rajgarh & 62.7 & 75.1 & 49.8 & 0.40 & 59.2 & 78.7 & 0.31 \\
\hline 37 & Vidisha & 72.1 & 81.4 & 61.7 & 0.27 & 68.6 & 83.1 & 0.20 \\
\hline 38 & Bhopal & 82.3 & 87.4 & 76.6 & 0.13 & 69.4 & 85.2 & 0.19 \\
\hline 39 & Sehore & 71.1 & 82.4 & 58.9 & 0.33 & 68.3 & 82.7 & 0.20 \\
\hline 40 & Raisen & 74.3 & 82.5 & 65.0 & 0.23 & 70.7 & 82.7 & 0.14 \\
\hline 41 & Betul & 70.1 & 78.4 & 61.6 & 0.24 & 65.7 & 87.8 & 0.32 \\
\hline 42 & Harda & 74.0 & 83.1 & 64.3 & 0.25 & 70.0 & 88.6 & 0.25 \\
\hline 43 & Hoshangabad & 76.5 & 85.2 & 67.0 & 0.24 & 71.1 & 88.6 & 0.23 \\
\hline 44 & Katni & 73.6 & 84.2 & 62.5 & 0.29 & 71.1 & 88.6 & 0.24 \\
\hline 45 & Jabalpur & 82.5 & 89.1 & 75.3 & 0.16 & 73.7 & 88.5 & 0.18 \\
\hline 46 & Narsinghpur & 76.8 & 85.2 & 67.6 & 0.23 & 74.2 & 87.7 & 0.13 \\
\hline 47 & Mandla & 68.3 & 79.5 & 57.2 & 0.33 & 65.4 & 87.9 & 0.33 \\
\hline 48 & Chhindwara & 72.2 & 80.8 & 63.4 & 0.24 & 67.5 & 86.6 & 0.26 \\
\hline 49 & Seoni & 73.0 & 81.8 & 64.1 & 0.24 & 70.7 & 89.7 & 0.26 \\
\hline 50 & Balaghat & 78.0 & 87.1 & 69.7 & 0.24 & 76.8 & 86.8 & 0.12 \\
\hline
\end{tabular}

Sources: Census of India, 2011

\section{Spatial Pattern of Male Literacy Rate}

Madhya Pradesh has 80.50 percent male literacy compare to 82.14 percent Indian male literacy rate. The district wise spatial pattern of male literacy rate in Madhya Pradesh is not uniform. It varies from 89.2 percent in Indore district to 43.6 percent in Alirajpur district. 
Table: 4. Variations of Male Literacy Rate in Madhya Pradesh

\begin{tabular}{|l|l|l|}
\hline $\begin{array}{l}\text { Categories of } \\
\text { literacy rate }\end{array}$ & No. of districts & Name of including districts \\
\hline Very high & 22 & $\begin{array}{l}\text { Satna, rewa, anuppur, neemuch, mandsaur, Ujjain, shajapur, dewas, indore, } \\
\text { vidisha, Bhopal, sehore, raisen, harda, hoshangabad, katni, Jabalpur, } \\
\text { narsinghpur, chhindwara, seoni, balaghat, bhind }\end{array}$ \\
\hline High & 19 & $\begin{array}{l}\text { Morena, Gwalior, datia, tikamgarh, chhatarpur, sagar, sidhi, singrauli, umaria, } \\
\text { dindori, shahdol, ratlam, dhar, khandwa, khangone, burhanpur, rajgarh, betul, } \\
\text { mandla }\end{array}$ \\
\hline Moderate & 5 & Shivpuri, guna, ashoknagar, panna, damoh \\
\hline Low & 3 & Sheopur, badwani, jhabua \\
\hline Very low & 1 & alirajpur \\
\hline
\end{tabular}

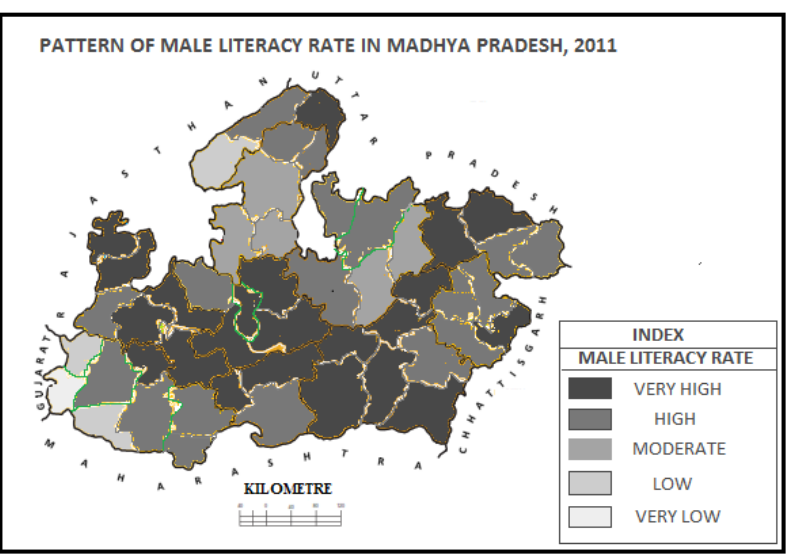

Fig.4 Pattern of Male Literacy Rate in Madhya Pradesh

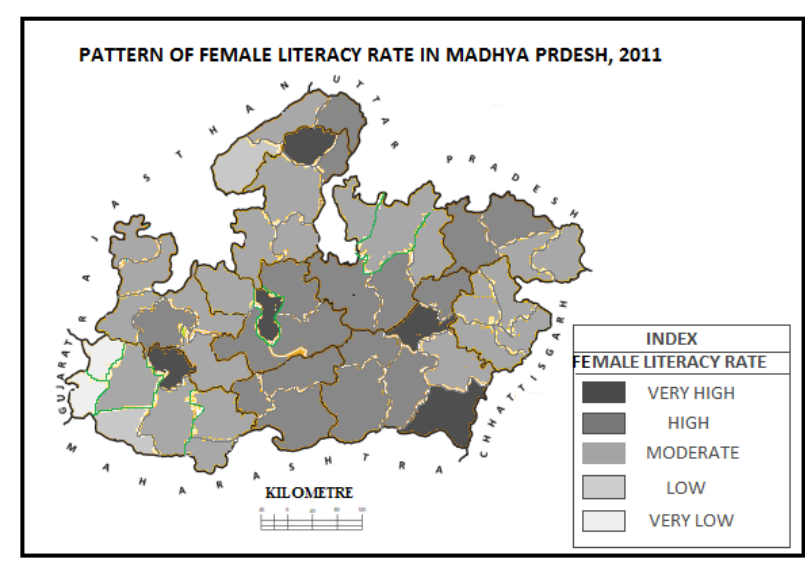

Fig. 5 Pattern of Female Literacy Rate in Madhya Pradesh

\section{Pattern of Female Literacy Rate}

Madhya Pradesh has 60.0 percent female literacy rate and it varies from highest in Bhopal (76.6 \%) to the lowest in Alirajpur (31.0\%) district. The spatial patterns of very high female literacy rate in five districts as: Bhopal (76.6\%), Gwalior (68.3\%), Indore (74.9\%), Jabalpur (75.3\%) and Balaghat (69.7\%) district in the state. High and moderate female literacy rate are a broad region of the state and low and very low female literacy rate in two small regions, one lies in northern part and second lies in south western part of the state.

Table: 5. Variations of Female Literacy Rate in Madhya Pradesh

\begin{tabular}{|c|c|l|}
\hline Categories of literacy rate & $\begin{array}{c}\text { No. of } \\
\text { districts }\end{array}$ & Name of including districts \\
\hline Very high $(<67.73 \%)$ & 5 & Gwalior, Indore, Bhopal, jabalpur, balaghat \\
\hline $\begin{array}{c}\text { High } \\
(58.54-67.72 \%)\end{array}$ & 17 & $\begin{array}{l}\text { Bhind, datia, sagar, damoh, satna, rewa, Ujjain, vidisha, sehore, raisen, betul, } \\
\text { harda, hoshangabad, katni, narsinghpur, chhindwara, seoni }\end{array}$ \\
\hline $\begin{array}{c}\text { Moderate } \\
(49.37-58.54 \%)\end{array}$ & 24 & $\begin{array}{l}\text { Morene, shivpuri, guna, ashoknagar, tikamgarh,chhatarpur, panna, sidhi, } \\
\text { singrauli, umaria, dindori, shahdol, anuppur, neemuch, mandsaur, ratlam, } \\
\text { shajapur, dewas, dhar, khargone, khandwa, burhanpur, rajgarh, mandla, }\end{array}$ \\
\hline $\begin{array}{c}\text { Low } \\
(40.18-49.36 \%)\end{array}$ & 2 & Sheopur, badwani \\
\hline $\begin{array}{c}\text { Very low } \\
(40.18 \%)\end{array}$ & 2 & Jhabua, alirajpur \\
\hline
\end{tabular}

\section{Spatial Pattern of Urban Literacy Rate}

Madhya Pradesh has 84.1 percent urban literacy which varies from the highest 89.7 percent in Seoni district to the lowest in 68.4 percent in Shivpuri district. For the spatial pattern of urban literacy rate in Madhya Pradesh has shows by Choropleth map. Thirteen districts are very high urban literacy and twenty districts have included of high urban literacy rate in the state while fourteen districts have included in low and very low urban literacy rate. 
Table: 6. Variations of Urban Literacy Rate in Madhya Pradesh

\begin{tabular}{|c|l|l|}
\hline $\begin{array}{c}\text { Categories of } \\
\text { literacy rate }\end{array}$ & $\begin{array}{c}\text { No. of } \\
\text { districts }\end{array}$ & Name of including districts \\
\hline $\begin{array}{c}\text { Very high } \\
(<85.45 \%)\end{array}$ & 13 & $\begin{array}{l}\text { Sagar, dindori, indore, betul, harda, hoshangabad, katni, Jabalpur, narsinghpur, mandla, } \\
\text { chhindwara, seoni, balaghat }\end{array}$ \\
\hline $\begin{array}{c}\text { High } \\
(81.19-\end{array}$ & 19 & $\begin{array}{l}\text { Gwalior, damoh, satna, rewa, shahdol, anuppur, mandsaur, neemuch, ratlam, Ujjain, shajapur, } \\
\text { dewas, khargone, khandwa, jhabua, vidisha, Bhopal, sehore, raisen }\end{array}$ \\
\hline $\begin{array}{c}\text { Moderate } \\
(76.93-\end{array}$ & 15 & $\begin{array}{l}\text { Morena, bhind, datia, guna, ashoknagar, chhatarpur, panna, singrauli, sidhi, umaria, dhar, } \\
\text { badwani, alirajpur, burhanpur, rajgarh }\end{array}$ \\
\hline $\begin{array}{c}\text { Low } 1.18 \%) \\
(72.67-\end{array}$ & 2 & Sheopur, Tikamgarh \\
\hline $\begin{array}{c}76.92 \%) \\
\text { Very low } \\
(>72.66 \%)\end{array}$ & 1 & Shivpuri \\
\hline
\end{tabular}

\section{Spatial Pattern of Rural Literacy Rate}

Madhya Pradesh has 65.3 percent rural literacy. District wise spatial pattern of rural literacy varies from highest in Balaghat (76.8\%) to the lowest in Alirajpur (33.2\%) district. 14 percent district under the low rural literacy and 36 percent district are high rural literacy rate in the state. 28 district of the state have more rural literacy than the state average.

Table: 7. Variations of Rural Literacy Rate in Madhya Pradesh

\begin{tabular}{|c|l|l|}
\hline $\begin{array}{c}\text { Categories of literacy } \\
\text { rate }\end{array}$ & $\begin{array}{c}\text { No. of } \\
\text { districts }\end{array}$ & Name of including districts \\
\hline $\begin{array}{c}\text { Very high }(<68.0 \%) \\
(59.3-68.0 \%)\end{array}$ & 19 & $\begin{array}{l}\text { Morena, bhind, datia, sagar, satna, rewa, mandsaur, indore, vidisha, Bhopal, sehore, } \\
\text { raisen, harda, hoshangabad, katni, Jabalpur, narsinghpur, seoni, balaghat }\end{array}$ \\
\hline $\begin{array}{c}\text { High } \\
59.2 \%)\end{array}$ & $\begin{array}{l}\text { Gwalior, shivpuri, guna, ashoknagar, tikamgarh, chhatarpur, panna, damoh, sidhi, umaria, } \\
\text { dindori, shahdol, anuppur, neemuch, ratlam, Ujjain, shajapur, dewas, khargone, khandwa, } \\
\text { betul, mandla, chhindwara }\end{array}$ \\
\hline $\begin{array}{c}\text { Low }(50.6- \\
(41.9-50.5 \%)\end{array}$ & 1 & Sheopur, singrauli, dhar, burhanpur, rajgarh \\
\hline Very low $(>41.9 \%)$ & 2 & badwani \\
\hline
\end{tabular}

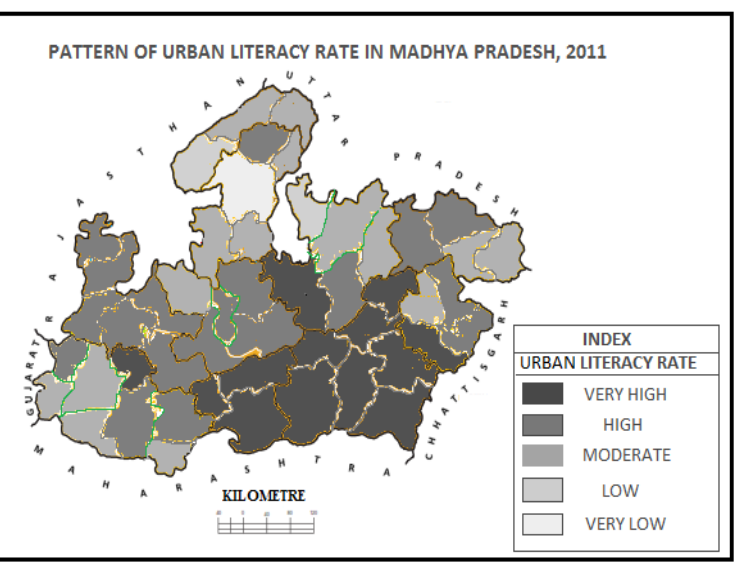

Fig.6 Pattern of Male Literacy Rate in Madhya Pradesh

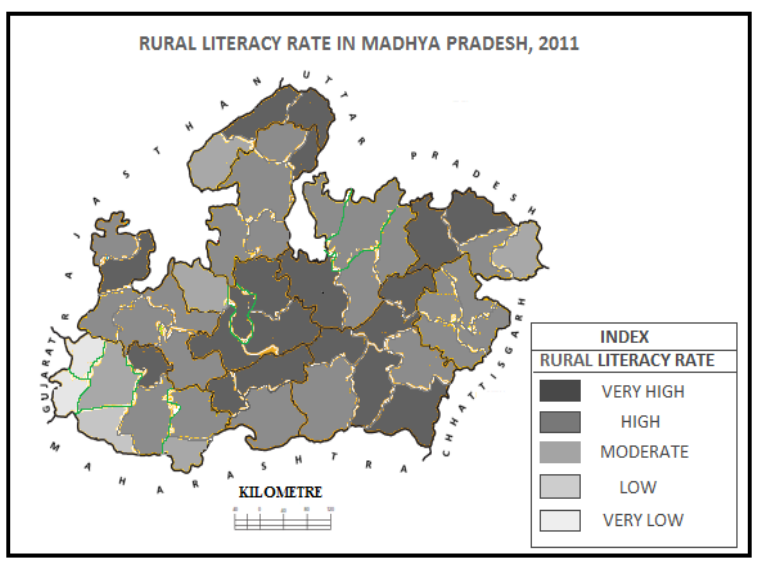

Fig. 7 Pattern of Female Literacy Rate in Madhya Pradesh

\section{Literacy Differentials}

This paper has been discussed the literacy differential of Madhya Pradesh. It varies from one district to another of male -female and urban -rural differential.

\section{Male- Female Literacy Differential}

There were large regional variations in terms of male-female differential in literacy rate. At the state level, male-female is 0.29 . This differential is highly pronounced in Jhabua (0.46) district followed by Sheopur 
(0.44), Shivpuri (0.42) and Neemuch (0.40) district also displayed a very high male-female differential in the literacy rate.

High male- female differential in literacy in these areas may be attributed to very low female literacy owing to prejudice against female education, economic backwardness and low level of urbanization, high rate of natural increase, low status of woman.

On the other hand male-female differential in literacy were recorded to be the lowest in Bhopal district (0.13). It was low also in Jabalpur (0.16), Indore (0.17) and Gwalior (0.23) district due to high level of socio economic development, high level of female literacy, highly developed infrastructural facilities, easy accessibility and availability of educational institutions.

\section{Rural-Urban Differential}

Literacy rate in Madhya Pradesh is marked by wide of rural-urban differentials. The average ruralurban differential index analyzed in the state was 0.27 point. This differential is highly pronounced in Alirajpur (1.28) district followed by Jhabua (1.00) Badwani (0.67) and Dhar (0.42) district also displayed a very high urban-rural differential in the literacy.

On the other hand urban-rural differential in literacy were recorded to be the lowest in Datia (0.11) district. It was low also in Shivpuri, Morena and Balaghat (0.12).

\section{Concluding Observation And Suggestion For Policy Recommendation}

It may be conclude that there is an increase in literacy rate in the state since independence, but it is insignificant in comparison to other states and union of the Country. There are wide gaps between male and female between urban and rural literacy rates. In rural areas parents discriminate the boys to give education. Poverty also compels the parents discriminate the girls preferring the boys to give education. Poverty also compels the parents to involve their children to sundry Works, rather than sending them to schools. Therefore in order to achieve the goal of universalization of education, more stress should be given for female literacy.

Differential in literacy by sex have to be narrowed down. Financial assistance should be granted to the weaker sections of the society in order to raise their socio-economic conditions especially in the country sides. The local bodies, NGOs and voluntary organizations have to be invited in this regard. It should not be the task of government only but each and every section of the society should be involved in such programmes. Some suggestions for education development that help grow of literacy rate in the state:

1. South western, north and north central and eastern part of the state are undeveloped due to physical barrier and tribal settlements are concentrated in these areas, so that the Government need to special attention grows the development facility in these areas that's helps to growing effect on literacy.

2. There is a wide gaps between male female and rural to urban literacy, so need to attention for woman empowerment and village empowerment for the male-female and urban-rural differential.

\section{References}

[1] Banerjee, Maya, (1975), "Literacy in Singhbhum, Bihar”, Geographical Review of India, Vol. 37, pp 151-157.

[2] Chandna, R.C.,(Oct.2009), "Literacy in Punjab and Haryana-2001”, Punjab Geographer, Volume 5, pp 116-120.

[3] Chandna, R.C. And Sidhu, M.(1980),"Introduction To Population Geography”, Kalyani Publishers, New Delhi.

[4] Dube, R.S. And Mishra, R.P. (1881), "Level of Education: A Versatile Indicator of Regional Development", Geographical Review of India, Vol. 43, No. 3, pp. 278-285.

[5] Goel, Sanjeev, (2013), "Spatial Pattern of Literacy in Haryana", Uttar Bharat Bhoogol Patrika, Vol. 43, No.3, pp 81-86.

[6] Gopal K. and Madhvir, S. (1977), "Literacy in India”, Geographical Review of India, Vol. 39, No. 2, pp. 117-125.

[7] Gosal,G.S. (1961), "Literacy In India; An Interpretative Study”, Rural Sociology, Vol. 29, pp261-277.

[8] Hassan, Mohammad Izhar (2009), "Population Geography", Rawat Publications,Jaipur.

[9] Jain, Savita,(1992) "Educational Level in Madhya Pradesh: A Geographical Analysis", Unpublished Ph.D. Thesis, Dr. Hari Singh Gour V.V. Sagar.

[10] Kumar, Pramila (2000), "Madhya Pradesh: Eak Bhougolik Adhyan", Madhya Pradesh Hindi Granth Academy Bhopal.

[11] Som, Kalyan Sundar and Mishra, R.P. (2014), "Literacy and Their Differential in West Bengal” International Journal of Science and Research, Volume 3, Issue 6, pp. 1537-1545.

[12] www.censusmp.nic.in 